\title{
Disiplin Gereja Berdasarkan Injil Matius 18:15-17 Dan Implementasinya Dalam Gereja Masa Kini
}

\section{Church Discipline Based on the Gospel Matthew 18: 15-17 and its implementation In the Church of the Present}

\author{
Yohanis Luni Tumanan ${ }^{1)^{*}}$ \\ 1)Almuni Program Doktor Sekolah Tinggi Theologia Jaffray \\ *) Penulis Korespondensi: hani_glorieslife75@yahoo.com
}

\begin{abstract}
Abstrak
Seringkali gereja mengalami kebingungan saat harus menentukan sikap terhadap orang yang berbuat dosa. Salah satu sikap yang ekstrim adalah membiarkan saja seseorang jatuh ke dalam dosa karena takut membuat orang itu tersinggung. Sikap ekstrim yang lain adalah sangat membenci dosa, sehingga membenci juga orang yang melakukannya. Disiplin dalam gereja merupakan kelalaian besar di sebagian gereja saat ini. Pemimpin takut untuk melakukan disiplin gereja kepada anggota jemaat, karena dinggap bertentangan dengan "kasih Allah" dan dapat menyebabkan perpecahan di dalam persekutuan. Pelaksanaan disiplin gereja disinyalir dapat menyebabkan hilangnya anggota jemaat yang berpengaruh dan kaya. Ada juga kesalah-pahaman besar tentang makna, tujuan, dan sifat disiplin gereja. Banyak yang melihat disiplin gereja sebagai kutukan dan pengucilan daripada cinta kasih yang memulihkan untuk mengembalikan kepada persekutuan dengan orang percaya. Artikel ini bermaksud menjelaskan pemahaman yang benar mengenai tidakan dan prosedur disiplin gereja yang alkitabiah berdasarkan Injil Matius 18:15-17.
\end{abstract}

Kata kunci: disiplin, gereja, jemaat, dosa, Matius 18:15-17

\begin{abstract}
Often churches are confused when it comes to determining the attitude toward those who sin. One extreme attitude is to let alone the person who falls into sin for fear of making him/her offended. The other extreme attitude is that we hate the sin so much, that we begin to hate the one who did it. The application of discipline in the church is often overlooked in most churches today. Leaders are afraid to discipline members of the church, because it is deemed contrary to the "love of God" and can lead to divisions in the congregation. The implementation of church discipline can allegedly cause the loss of influential and rich members of the congregation. There is also a big misconception about the meaning, purpose, and the nature of church discipline. Many see church discipline as a curse and exclusion rather than love that restores the fellowship of believers. This article aims to explain the correct understanding of the act of and procedures of biblical church discipline based on Matthew 18: 15-17.
\end{abstract}

Keywords: discipline, church, congregation, sin, Matthew 18:15-17 


\section{Pendahuluan}

Dalam Matius 18:15-17, Tuhan Yesus memberikan instruksi tentang apa yang seharusnya dilakukan jika ada seorang anggota jemaat yang berbuat dosa. Langkah awal adalah menegurnyadi bawah empat mata. Apabiladia tidak mau bertobat, menegurnya di depan satu atau dua orang saksi. Jika dia tetap tidak mau bertobat, mengumumkan masalah itu kepada jemaat. Jika dia tidak mau mendengarkan jemaat, dia harus dikenakan siasat gerejawi. Instruksi yang diberikan oleh Tuhan Yesus ini penting, karena dosa yang dibiarkan akan membawa dampak negatif terhadap gereja, yaitu bahwa dosa tidak dianggap sebagai masalah serius, padahal dosa itu mendukakan hati Tuhan, apabila berkompromidengan dosa.

Genre perikop Matius 18:15-17 benar-benar sudah dipertimbangkan, baik konteks sebelum dan sesudahnya, maupun konteks secara keseluruhan yang memperlihatkan bahwa Matius menulis Injil ini dengan penekanan pedagogis. Injil Matius 18:15-17 dengan jelas menyatakan keharusan ini. Mengingat prosedur dalam Matius 18:15-17 dengan kata kerja perintah "pergi", maka disiplin gereja tidak hanya disarankan, tetapi itu diperlukan. ${ }^{1}$

\section{Tafsiran Perikop Matius 18:15-17}

Yesus memberikan instruksi kepada murid-murid-Nya seperti yang tertulis sebagai berikut:

${ }^{15(a)}$ Apabila saudaramu berbuat dosa, (b)tegorlah dia di bawah empat mata. (c) Jika ia mendengarkan nasihatmu (d)engkau telah mendapatnya kembali. 16(a) Jika ia tidak mendengarkan engkau, (b) bawalah seorang atau dua orang lagi, 'supaya atas keterangan dua atau tiga orang saksi, perkara itu tidak disangsikan. ${ }^{17(a)} \mathrm{Jika}$ ia tidak mau mendengarkan mereka, ${ }^{(b)}$ sampaikanlah soalnya kepada jemaat. (c)Dan jika ia tidak mau juga mendengarkan jemaat, (d)pandanglah dia sebagai seorang yang tidak mengenal Allah atau seorang pemungut cukai. $^{2}$

Dari segi analisis konteks, ayat-ayat ini merupakan bagian pengajaran yang berhubungan dengan kepedulian terhadap anak-anak Kerajaan, menyelamatkan domba yang hilang, dan mengampuni saudarasaudara. Keener mengatakan, "Ayat-ayat tentang disiplin sangat erat kaitannya dengan ayat sebelumnya tentang mencari domba yang

${ }^{1} \mathrm{H}$. Wayne House, "Church Discipline and the Courts," The Southern Baptist Journal of Theology 4, No. 4 (Winter 2000): 61.

${ }^{2}$ Matius 18:15-17 (TB). 
tersesat." Dalam konteks ini pengampunan memiliki kemungkinan yang sangat besar, tujuan utamanya adalah untuk pemulihan, bahkan ketika harus melakukan tindakan pengucilan seseorang dari gereja sekalipun. ${ }^{3}$

Seluruh pasal 18 diucapkan pada satu waktu dalam pengajaran Yesus Kristus, menjelang pelayanan-Nya di Galilea akan segera berakhir. Ini adalah kunjungan Yesus yang terakhir ke Kapernaum. Tentang pasal 18, Heer mengatakan,

Pasal 18 biasanya dinamai kumpulan peraturan-peraturan Yesus bagaimana anggota jemaat Kristen harus bergaul dengan anggota-anggota lain dalam jemaat itu. Atau lebih pendek: peraturan-peraturan tentang jemaat. Pengarang Injil Matius suka menyebut ajaran-ajaran dan perbuatan Yesus dengan cara yang sistematis. Mungkin justru susunan yang sistematis itu Injil Matius banyak dipakai di gereja dan ditempatkan dimuka buku-buku Injil yang lain. ${ }^{4}$

Royal van Gorcum mengatakan, bahwa ayat 15-17 relevan dalam hal yang lain juga. Apabila dipisahkan dari konteksnya, ayat-ayat ini mengandung aturan halakha (hukum sipil dan hukum agama Yahudi) tentang bagaimana menanggapi pelanggaran pribadi yang dilakukan oleh sesama orang percaya. ${ }^{5}$ Dengan memerhatikan ayat-ayat di atas, maka terlihat jelas proses dan prosedur dalam melaksanakan disiplin gereja. Teks ini berisi perintah ilahi untuk melaksanakan disiplin gereja secara teratur. George Davis mendefinisikan disiplin gereja sebagai penerapan prinsip dan prosedur Alkitab dengan setia dalam jemaat lokal untuk menjaga kemurnian ajaran, kesucian hidup, dan efisiensi yang bermanfaat di antara anggotanya. ${ }^{6}$ Tuhan Yesus Kristus menetapkan prinsip dan prosedur tersebut sebagai koreksi di dalam gereja-Nya.

Struktur pasal 18:15-17 secara bergantian antara klausa kondisional (dengan ean) yang diikuti dengan (aorist subjunctive) dan konsekuensi (dengan kata perintah). Klausa kondisional ini menyajikan hipotesis situasi konfrontasi (18:15a, 16a, 17a, 17c). Dengan segera diikuti oleh perintah yang mengharuskan respons yang tepat (18:15, 16b, 17b, 17d). Pola ini rusak dua kali, pertama di 18:15c-d, yang menggambarkan hipotesis respons positif dan rekonsiliasi dihasilkan. Ini terbukti, bahwa respons rekonsiliasi positif adalah mungkin pada langkah konfrontasi

${ }^{3}$ Craig S. Keener, Matthew: The IVP New Testament Commentary Series (Downes Grove, IL: InterVarsity, 1997), 287-288.

${ }^{4}$ J. J. de Heer, Tafsiran Alkitab: Injil Matius Pasal 1-22 (Jakarta: BPK Gunung Mulia, 2013), 351.

${ }^{5}$ Royal van Gorcum, Matthew and Didache: Two Documents from the Same Jewish-Christian Mileu? (Minneapolis: Portress Press, 2005), 176.

${ }^{6}$ George B. Davis, "Whatever Happened to Church Discipline," Criswell Theological Review 1 (Spring 1987): 345. 
kemudian dan tersirat setelah 18:16c, 17b, dan bahkan mungkin $17 \mathrm{~d}$. Interupsi lainnya adalah pada 18:16c, di mana dukungan alkitabiah untuk dua atau tiga orang saksi (lihat 18:19-20) pada langkah kedua disimpulkan.

Strukturnya dapat dilihat seperti yang ditawarkan oleh David L. Turner di bawah ini: ${ }^{7}$

Struktur Matius 18:15-17

A. Hipotesis pelanggaran awal (ay. 15a)

Langkah pertama: Teguran pribadi (ayat. 15b).

Hipotesis respons positif (ay. 15c).

Rekonsiliasi (ay. 15d).

B. Hipotesis respons negatif untuk teguran pribadi (ay. 16a)

Langkah kedua: Teguran dengan menghadirkan saksi (ay. 16b)

Dukungan Alkitab (ay. 16c).

C. Hipotesis respons negatif untuk teguran dengan menghadirkan saksi (ay. 17a).

Langkah ketiga: Teguran publik (ay. 17b).

D. Hipotesis respons negatif untuk teguran langkah ketiga (ay. 17c).

Langkah keempat: Ekskomunikasi (pengucilan) (ay. 17d).

Struktur di atas memperlihatkan instruksi jelas tentang disiplin gereja. Berdasarkan catatan Turner, jelas bahwa respons positif dan rekonsiliasi sangat mungkin terjadi pada $18: 15 c-d$, hanya membicarakan tentang pertobatan dan pemulihan kemungkinan terjadi pada setiap langkah dari setiap proses, dan akan mengurangi keharusan untuk membawa proses lebih lanjut. Philip Mutetei menjelaskan bahwa dalam Matius 18:15-17, Yesus memberikan empat langkah yang harus diambil dalam proses disiplin sebagai kondisi yang harus diambil yang meliputi teguran pribadi, teguran dengan menghadirkan saksi, teguran publik, dan pengucilan. ${ }^{8}$ Berdasarkan struktur yang tampak dalam uraian di atas, maka ditemukan indikator empat langkah dalam proses pelaksanaan instruksi tentang disiplin gereja yang akan dijabarkan sebagai berikut:

\section{Teguran Pribadi}

Ayat 15 berkata, "Apabila saudaramu berbuat dosa [terhadapmu], tegurlah dia di bawah empat mata. Jika ia mendengarkan nasihatmu engkau telah mendapatnya kembali." Kata jika (if), bentuk Yunaninya dikenal sebagai kalimat yang bersyarat umum. Jadi intinya adalah jika

${ }^{7}$ David L. Turner, Matthew: Baker Exegetical Commentary on the New Testament (Grand Rapids, Michigan: Baker Academic, 2008), 443-444.

'Philip Mutetei, "The Proper Procedure for Discipline in the Church Part II," Africa Journal of Evangelical Theology 18, No. 2 (1999): 111. 
saudara berbuat dosa terhadap Anda, maka ada prinsip-prinsip yang mengikuti ketika dia melakukannya. ${ }^{9}$ Kata Yunani untuk menegur yang digunakan ayat 15 adalah elenchō yang berarti untuk membawa pada terangatau meyakinkan seseorang dari sesuatu. Ini berarti hal yang paling alkitabiah dan penuh kasih yang dapat dilakukan untuk saudara yang berbuat dosa adalah menegur untuk menunjukkan kesalahannya melalui kebenaran dan solusi untuk perbuatan dosa seseorang. ${ }^{10}$ Selanjutnya ayat 15 mengidentifikasi, bahwa orang pertama yang mencari rekonsiliasi adalah orang yang menyadari pelanggaran dan tindakan koreksi individu dilakukan melalui konteks konfrontasi satusatu.

Daniel Cawdrey menjelaskan frasa ungkapan ayat 15 tersebut dengan mengatakan,

Pergi dengan cepat, penundaan mungkin berbahaya; jangan menunggu sampai ia datang kepada Anda, meskipun itu mungkin ia lebih baik di mata Anda sebelumnya, namun ia telah berbuat salah, dan telah melakukan pelanggaran. Memang ada perintah untuk ini, "Jika engkau mempersembahkan persembahanmu di atas mezbah dan engkau teringat akan sesuatu yang ada dalam hati saudaramu terhadap engkau, tinggalkanlah persembahanmu di depan mezbah itu dan pergilah berdamai dahulu dengan saudaramu" (Mat. 5:23). Tetapi sebagai orang Kristen yang sejati dorongan untuk pergi kepada saudara yang melakukan pelanggaran mempunyai beberapa alasan ini: 1) Mungkin ia tidak berpikir bahwa Anda tersinggung diluar ketidaktahuannya; 2) Ia tidak berpikir bahwa apa yang dilakukannya adalah suatu pelanggaran atau dosa; 3) Jika demikian, mungkin ia tidak menyadari bahwa ia memerlukan penebusan, bahkan ia membutuhkan rekonsiliasi; 4) Dia berada di bawah beberapa gangguan kesehatan, atau nafsu, amarah, rasa malu, dan begitu juga karena mabuk atau sakit. ${ }^{11}$

William Hendriksen mengatakan, "Yesus sedang berbicara tentang pelanggaran pribadi yang mendasari persyaratan untuk menunjukkan kasih dan semangat pengampunan terhadap semua membuatnya masuk akal untuk menyatakan, bahwa setiap kali kepentingan permintaan gereja, aturan Matius 18:15 harus juga dapat diterapkan untuk dosa-dosa secara umum..$^{12}$ Selanjutnya dengan menggunakan istilah "saudara" Yesus mendorong pendekatan kerendahan hati. Sikap kerendahan hati dibukti-

${ }^{9}$ Dan Doriani, "Forgiveness: Jesus Plan for Healing and Reconciliation in the Church (Matthew 18:15-35)," Southern Baptist Journal of Theology 13, No. 3 (2009):23.

${ }^{10}$ Mutetei, 112.

${ }^{11}$ Daniel Cawdrey, A Discourse on Church Discipline and Reformation (London: Puritan Publications, 2012), 16.

${ }^{12}$ William Hendriksen, New Testament Commentary Matthew (Grand Rapids, MI: Baker Book House, 1995), 698. 
kan bukan dengan pasif menunggu seseorang untuk meminta maaf baru memberikannya. Sebaliknya, hal itu diwujudkan dengan cara aktif mencari saudara yang sesat dan berupaya untuk membuatnya bertobat. ${ }^{13}$ Konfrontasi itu dilakukan untuk menyoroti perbuatan salah yang memerlukan pertobatan. Pendekatan ini dimaksudkan untuk memenangkan saudara, bukan untuk mencelanya di depan publik. Pertanyaannya adalah seberapa seringkah orang yang berdosa diberikan teguran secara pribadi sebelum melangkah ke proses berikutnya?

Adams menuliskan demikian untuk menjawabnya,

Mungkin saudara akan merasa perlu untuk mencoba beberapa kali, atau saudara mungkin ingin melakukan pendekatan yang bervariasi. Saudara ingin memastikan bahwa dengan semangat lemah lembut dan dengan tidak menjauhi dia. Selain itu, saudara harus membedakan dengan cermat antara keengganan untuk mendengarkan dan kegagalan untuk memahami atau menerima sudut pandang saudara tentang masalah tersebut. Jika saudara atau saudari terus membahas masalah ini dengan Anda, meminta bukti lebih lanjut, mengatakan bahwa ia memahami fakta-fakta yang berbeda, atau jika ia yakin bahwa penafsiran saudara dari ayat-ayat Alkitab yang berhubungan dengan kasus ini salah, maka saudara berkewajiban untuk mempertimbangkan hal ini. ${ }^{14}$

Yesus dengan sangat hati-hati menguraikan garis besar prosedur untuk memungkinkan saudara yang bersalah mengakui dosanya dan bertobat. Karena pelanggaran sifatnya pribadi, maka yang merasa terganggu harus menghadapi orang yang bersalah dengan empat mata dalam rangka untuk membuatnya sadar (elengchon kata ini bermaksud untuk menyatakan bahwa seseorang telah melakukan kesalahan dengan implikasi bahwa ada bukti yang memadai dari pelanggaran itu). Jika individu mendengarkan (meyakinkan dirinya bersalah dan mencari pengampunan), maka hubungan yang terputus telah dipulihkan (Anda telah memenangkan saudaramu). Dengan demikian, para murid tidak lagi berisiko kehilangan saudara atau saudari. ${ }^{15}$

Ungkapan "telah mendapatnya" dalam Matius 18:15, berasal dari kata Yunani kerdainô (memperoleh) yang berarti untuk mendapatkan keuntungan atau terhindar dari kerugian, tetapi arti yang lebih umum adalah untuk memenangkan sesuatu atau untuk menyelamatkan

${ }^{13}$ Stanley D. Toussaint, Behold the King: A Study of Matthew (Portland: Multnomah Press, 1980), 217.

${ }^{14}$ Jay E. Adams, Handbook of Church Discipline: A Right and Every Church Member (Grand Rapids, Michigan: Zondervan, 1986), 58.

${ }^{15}$ Larry Chouinard, Matthew: The College Press Niv Commentary (Joplin, Missouri: College Press, 1997), 327. 
seseorang. ${ }^{16}$ Kata tersebut adalah istilah dari dunia komersial dan digunakan untuk berbicara tentang pengumpulan kekayaan dalam arti uang atau komoditas. Istilah ini digunakan dalam pengertian Injil Matius 18:15, untuk menggambarkan bahwa seorang saudara yang berdosa sama dengan kehilangan harta yang berharga.

Hal ini sebagaimana terungkap dalam Matius 18:12-14, berarti Allah tidak akan membiarkan satu jiwa terhilang karena setiap orang berharga bagi-Nya. Keinginan Yesus terungkap dalam Matius 18:15, bahwa setiap orang percaya perlu memiliki perhatian yang sama, bahwa dosa seorang saudara adalah kerugian, sebab ada harta yang hilang dari kita, tetapi ketika restorasi berlangsung kekayaan itu kembali. Dengan demikian, seorang saudara yang berdosa seharusnya dikembalikan karena mereka berharga bagi Allah dan bagi kita.

Namun, Morris lebih jauh menjelaskan, apabila kata "terhadapmu" memang termasuk di dalam teks, maka Yesus menunjuk pada apa yang harus dilakukan ketika seorang percaya melakukan sesuatu hal yang dianggap sebagai dosa terhadap kita, karena melukai dengan berbagai cara. Dengan kata lain Yesus membicarakan apa yang harus dilakukan ketika orang lain melakukan dosa. ${ }^{17}$ Sedangkan Metzger berkomentar dengan mengatakan,

Telah banyak perdebatan mengenai apakah kata "terhadapmu" adalah bagian dari teks asli Yunani. Kata-kata tersebut tidak terdapat dalam beberapa naskah penting seperti Codex Vaticanus dan Codex Sinaiticus. Ada kemungkinan bahwa kata-kata "terhadapmu" dalam ayat 21 dituntun oleh seorang juru tulis atau penyalin untuk menyesuaikan materi dalam ayat 15. Di sisi lain, mungkin kelalaian itu disengaja untuk membuat bagian tersebut berlaku untuk dosa secara umum. ${ }^{18}$

Tetapi, Gundry mengungkapkan bukti orisinalitasnya dengan mengatakan, "Kata-kata dalam klausa berikutnya, "antara engkau dan dia saja" (NASB), dan bagian berikutnya yang berbicara tentang memaafkan seseorang yang telah berdosa terhadap saudara (18:21-35) mendukung orisinalitas "terhadapmu." ${ }^{19}$ Apabila dikombinasikan dengan ayat 15 ini frasa "antara engkau dan dia saja", semakin lama membacanya membuat jelas bahwa situasi yang digambarkan dalam ajaran Yesus melibatkan dosa yang dilakukan secara langsung terhadap sesama orang

${ }^{16} \mathrm{H}$. Schlier, Teological Dictionary of the New Testament, ed. Gerhard Kittel and Gerhard Friedrich (Grand Rapids: Eerdmans, 1967), 672-673, s.v. "kerdaino".

${ }^{17}$ Morris, 466-467.

${ }^{18}$ Bruce M. Metzger, Textual Commentary on the Greek New Testament (London: United Bible Societies, 1971), 45.

${ }^{19}$ Robert. H. Gundry, Matthew: A Commentary on His Literary and Theological Art (Grand Rapids: K. Eerdmans Publishing Co., 1982), 367. 
Kristen. ${ }^{20}$ Tetapi yang jauh lebih penting adalah bagaimana menerapkan teks tersebut dalam kaitan dengan disiplin gereja, sebagaimana komentar J. Carl Laney demikian,

Apakah kata-kata "terhadapmu" ada dalam teks asli atau tidak, namun itu jelas dari Gal. 6:1, bahwa orang-orang percaya memiliki tanggung jawab untuk menghadapi dosa secara umum, tidak hanya ketika itu adalah pelanggaran terhadap seseorang saja. Yesus dan Paulus menyerukan kepada orang-orang percaya untuk peduli terhadap kehidupan orang lain. Mereka bertanggung jawab untuk mengambil tindakan yang penuh kasih ketika seorang saudara atau saudari sedang menuju bencana spiritual. ${ }^{21}$

Tanggung jawab kita terhadap saudara yang berdosa, tidak dibangun melalui fakta bahwa ia telah bersalah kepada kita, tetapi oleh kenyataan bahwa ia telah berbuat dosa dan merugikan dirinya sendiri. Inilah proses awal dari pelaksanaan disiplin gereja sebagai ajaran Yesus yang didelegasikan-Nya kepada gereja mula-mula dan diteruskan hingga kini.

Tuhan Yesus memerintahkan untuk memberikan teguran kepada saudara seiman yang melakukan dosa (18:15). Dalam teks Yunani, sebelum perintah "tegurlah" ada kata "pergilah". Yesus mengatakan, bahwa saudara harus ditegur. Teguran adalah kata kuat yang dapat berarti untuk membawa kepada terang, menginsyafkan, atau meyakinkan seseorang dari sesuatu. Kata ini menyiratkan suatu peringatan yang membawa pada keyakinan.

Berdasarkan Matius 18:15 tidak ada keterangan eksplisit tentang jenis dosa yang dilakukan. Meskipun demikian, dosa yang perlu dikenakan disiplin adalah yang berpotensi merusak keselamatan seseorang. Ungkapan "engkau telah mendapatkannya kembali" menyiratkan, bahwa orang yang ditegur melakukan sebuah dosa yang serius dan membuat dia terhilang.Keseriusan ini lebih terlihat jelas apabila dikaitkan dengan perumpamaan tentang domba yang tersesat di 18:12-14. MacArthur menjelaskan,

Orang yang harus didisiplin adalah saudara yang berdosa. Dalam konteks ini, seperti dalam banyak tempat lain dalam Alkitab. Kata saudara mengacu pada setiap sesama orang percaya, baik laki-laki maupun perempuan. Calon disiplin konfrontatif adalah orang Kristen yang berbuat dosa. Implikasinya, bahwa hal itu adalah dosa yang terus-menerus dalam kehidupan seseorang

${ }^{20}$ Jeffrey A. Gibbs dan Jeffrey J. Kloha, "Following Matthew 18: Interpreting Matthew 18:15-20 in Its Context," Concordia Journal (January 2003): 15.

${ }^{21}$ J. Carl Laney, A Guide to Church Discipline: God's Loving Plan for Restoring Believers to Fellowship with Himself and with the body of Christ (Eugene: Bethany House Publisher, 1985), 49. 
dan belum diakui. Makna kata saudaramu adalah benar-benar inklusif, tanpa pengecualian. Setiap anak Tuhan, apakah tua atau muda, pria atau wanita, berpendidikan atau tidak berpendidikan, kaya atau miskin, pemimpin atau pengikut, harus dihadapkan ketika ia berdosa. Dosa dari hamartanô, yang memiliki arti harfiah "tidak mengenai sasaran" dan kata kerja dasar Perjanjian Baru berarti tidak memenuhi standar Allah. Dosa yang dilakukan oleh orang percaya, membutuhkan disiplin dari gereja. ${ }^{22}$

Orang yang melihat saudaranya terjatuh harus mengambil inisiatif untuk mendamaikan si pelaku (18:15). Perhatikan bahwa Yesus jelas memanggil kita untuk menegur orang lain karena dosa, bahkan menegur mereka secara terbuka jika diperlukan (Mat. 18:15), hal ini bukanlah menghakimi seperti tertulis dalam Matius 7, melainkan amanat Yesus dalam Matius 18. ${ }^{23}$ MacArthur menjelaskan, "Menegur adalah dari kata Yunani elencho, yang memiliki makna dasar yaitu "membawa terang" atau "mengekspos". Kata kerja ini berada dalam (aorist imperative), yang menunjukkan bahwa dosa saudara harus ditunjukkan sedemikian rupa, sehingga tidak dapat melarikan diri dan mengaku dosa apa adanya. ${ }^{24}$

\section{Teguran dengan Menghadirkan Saksi}

Ayat 16, "Jika ia tidak mendengarkan engkau, bawalah seorang atau dua orang lagi, supaya atas keterangan dua atau tiga orang saksi, perkara itu tidak disangsikan. Bagian ini membicarakan soal pelibatan saksisaksi yang mengetahui pelanggaran seorang saudara dan dan mempunyai tanggung jawab untuk menasihatinya. Idealnya, kita berharap tidak perlu untuk mengambil beberapa saksi. Kita menunjuk-kan dosa, mendorong pertobatan, dengan sentuhan ringan dan penuh kasih agar masalah ini diselesaikan, sehingga tidak perlu melanjutkan ke proses yang lebih menakutkan. ${ }^{25}$ Tetapi perlu dicatat bahwa orang bersalah yang tidak responsif membutuhkan tindakan publik yang kuat. ${ }^{26}$

Siapa yang harus menjadi saksi? Kata-kata Yesus tidak menunjuk orang tertentu selain untuk mengatakan "satu atau dua orang lain." Ini berarti bahwa mereka haruslah anggota dari gereja yang sama dengan pelaku. Dalam terang Galatia 6:1, orang tersebut seharusnya anggota jemaat yang dewasa secara rohani dan mampu memberikan nasihat yang

22 John MacArthur, Matthew 16-23: The MacArthur New Testament Commentary (Chicago: Moody, 1988), 126.

${ }^{23}$ Mark Dever, "Biblical Church Discipline," Southern Baptist Journal of Theology 4 No. 4 (Winter 2000): 29.

${ }^{24}$ MacArthur,128.

${ }^{25}$ Dan Doriani, "Forgiveness: Jesus Plan for Healing and Reconciliation in the Church (Matthew 18:15-35)," Southern Baptist Journal of Theology 13 No. 3 (2009): 25.

${ }^{26}$ Philip Mutetei, "The Proper Procedure for Discipline in the Church Part II," Africa Journal of Evangelical Theology 18 No. 2 (1999): 115. 
bijaksana dengan kata-kata kesaksian jika diperlukan, yang dihormati oleh jemaat. Umumnya orang seperti ini mungkin pendeta, penatua, diaken atau panutan rohani lainnya yang dihormati. ${ }^{27}$

Secara implisit Yesus memperingatkan kepada orang Kristen, bahwa saudara yang sudah ditegur secara pribadi tetapi tidak bertobat, maka tidak boleh menyerah. Sebaliknya, harus memanggil satu atau dua saksi untuk menghadapi saudara yang berbuat dosa dan memohon dengan dia untuk bertobat. Hal ini menunjukkan kepedulian yang serius terhadap saudara yang berdosa. Mereka hadir untuk berusaha meyakinkan orang yang berdosa, kesaksian mereka membantu untuk membuktikan bahwa ia bersalah. Lebih lanjut W. C. Allen menjelaskan,

Dua atau tiga adalah orang Kristen yang terganggu dan satu atau dua adalah yang diambil sebagai saksi. Masalah ini tidak diperlakukan secara ketat dari sudut pandang hukum, karena orang yang terganggu tidak akan diperhitungkan sebagai saksi di pengadilan. Selain itu, satu atau dua bukan dimaksudkan untuk menyaksikan pelanggaran, tetapi dimaksudkan bagi orang bersalah yang keberatan untuk didamaikan, dan upaya yang dilakukan oleh pihak yang terganggu adalah membawanya untuk rekonsiliasi. ${ }^{28}$

R. H. Gundry berpendapat, bahwa Matius tidak meninggalkan indikasi bahwa satu atau dua orang lain akan menyaksikan dosa yang dilakukan terhadap seseorang yang membawa mereka serta. Oleh karena itu, mereka tidak memiliki tujuan untuk membangun tuduhan berat atau memungkinkan mereka untuk bertindak sebagai saksi sebelum gereja dalam kasus penolakan kedua, namun penguatan teguran bertujuan ke arah pemulihan. ${ }^{29}$ Sejalan dengan Blomberg yang mengatakan, bahwa saksi di sini bukan berarti saksi tentang dosa yang dilakukan, melainkan saksi sebagai upaya untuk menunjukkan kesalahan dari orang yang berdosa. ${ }^{30}$

Alasan lain untuk partisipasi para saksi adalah mereka diperlukan sebelum masalahnya disampaikan kepada persekutuan jemaat untuk tujuan disiplin. Pada awalnya hal ini tidak jelas apakah fungsi dari saksi adalah untuk mendukung orang yang menghadapi saudaranya yang sesat dengan membawa kesaksian tambahan tentang dosa yang dilakukan atau untuk memberikan kesaksian tentang konfrontasi. Tetapi Calvin

${ }^{27}$ David L. Burggraf, "Principles of Discipline in Matthew 18:15-17 Part III: A Practical Study," Calvary Baptist Theological Journal 5 (Fall 1989): 17.

${ }^{28}$ Allen, 198.

${ }^{29}$ Gundry, 368.

${ }^{30} \mathrm{C}$. L. Blomberg, Commentary of the New Testament Use of the Old Testament (Grand Rapids: Baker Academic, 2007), 56. 
mengatakan, bahwa tujuan dari saksi ini adalah untuk memberikan bobot yang lebih besar dan impresif untuk nasihat. ${ }^{31}$

Oleh karena itu, masuk akal untuk menyimpulkan bahwa Kristus memerintahkan saudara yang tidak bertobat untuk berhadapan secara pribadi dengan satu atau dua saksi tambahan. Tujuan dari saksi adalah untuk membujuk saudara yang berbuat dosa supaya bertobat, sehingga memungkinkan dia dikembalikan ke dalam komunitas persekutuan orang percaya.

Keterlibatan dua atau tiga saksi dalam sebuah perkara bersumber dari ajaran Perjanjian Lama (Im. 19:15). Selanjutnya orang-orang Yahudi dan gereja mula-mula tetap mengadopsi prinsip ini (Yoh. 8:17; 2 Kor. 13:1; 1 Tim. 5:19; Ibr. 10:28).Sejauh ini para Rabbi Yahudi memiliki prinsip, bahwa satu orang saksi tidak cukup, walaupun saksi mata menangkap tangan orang yang bersalah. Prosedur disiplin ketat sedang dijalankan pada titik ini, karena tindakan yudisial sedang berlangsung. Di sini Yesus setuju dengan praktik Yahudi perihal teguran pribadi, pengambilan saksi, dan akhirnya sidang pengadilan, jika pertobatan tidak terjadi. ${ }^{32}$

Dalam konteks disiplin gereja, tentu saja saksi di sini bukan sembarang saksi. Tuhan melarang orang mengucapkan saksi dusta (Kel. 20:16; Ul. 5:20). Saksi yang dimaksud adalah orang lain yang tahu masalah atau termasuk pemimpin gereja untuk memperkuat teguran dan menyebabkan pelaku untuk menyadari keseriusan situasi. Hal ini selalu menjadi maksud yang indah dari pelaksanaan disiplin gereja. J. J. de Heer mengatakan,

Dua atau tiga orang lain harus diikutsertakan dalam teguran, dengan tiga alasan: (1) Teguran yang diberikan oleh tiga orang adalah lebih kuat daripada teguran yang diucapkan satu orang saja. (2) Dengan dua orang tambahan itu pembicaraan akan menjadi lebih matang dan lengkap. (3) Andaikata orang yang ditegur itu tetap berkeras, maka dua orang tambahan itu dapat menjadi saksi di depan jemaat tentang pembicaraan yang telah diadakan. ${ }^{33}$

Kehadiran saksi dapat berguna untuk mencapai perubahan secara bertahap bagi orang yang bersalah. Sementara itu saksi dapat berfungsi untuk membawa objek permasalahan pada situasi yang lebih besar. Tujuan utamanya adalah untuk memperkuat teguran, dengan demikian menyebabkan orang yang berdosa bertobat. Tujuan utama dari para

${ }^{31}$ John Calvin, Commentary on a Harmony of the Evangelists, Matthew, Mark, and Luke Vol. 1 (Grand Rapids: Baker Book House, 1996), 355.

${ }^{32}$ Craig S. Keener, The IVP Bible Background Commentary New Testament (Downers Grove, Illinois: InterVarsity Press, 1993), 94.

${ }^{33}$ Heer, 364. 
saksi di sini adalah untuk menegaskan kepedulian kepada pihak yang bersalah dan untuk meningkatkan persuasi persaudaraan terhadap saudara yang berdosa agar menyadari situasi yang serius. Hal itu dijelaskan oleh Wiersbe sebagai berikut:

Jika orang berdosa menolak untuk membuat hal yang benar, maka kita dapat merasa bebas untuk berbagi beban dengan satu atau dua orang percaya yang diandalkan. Kita harus berbagi fakta sebagaimana yang disaksikan, lalu menasihati dan mendoakannya. Setelah penyebabnya jelas, kemudian bersama-sama kita bisa pergi kepada saudara yang berdosa dan mencoba sekali lagi untuk memenangkan dirinya. Tidak hanya membantunya dalam doa dan meyakinkannya, tetapi mereka dapat menjadi saksi kebenaran di hadapan jemaat (Ul. 19:15; 2 Kor. 13:1). Ketika dosa tidak ditangani dengan jujur, akan selalu menyebar. Apa yang pernah menjadi masalah antara dua orang dapat menyebar dengan melibatkan empat atau lima orang. Tidak heran Yesus dan Paulus membandingkan dosa dengan ragi, karena ragi itu menyebar. ${ }^{34}$

Penjelasan Warren W. Wiersbe bersifat nasihat dan bimbingan sebagai bentuk teguran bersama agar pelaku menyadari kesalahannya, tetapi jika orang itu tetap menolak, maka saksi akan memberikan keterangan pada persidangan majelis sebelum di depan seluruh jemaat. Seperti dalam teguran pribadi, tujuan tahap kedua adalah terutama penebusan untuk mendamaikan orang berdosa yang terluka dan kemudian membawa mereka kembali kepada Allah. ${ }^{35}$ Hanya ketika saudara yang bersalah tetap menolak upaya rekonsiliasi, maka satu atau dua orang mempunyai tugas tambahan sebagai saksi, seperti penjelasan Jay E. Adams yang mengatakan,

Para saksi bukan hanya bersaksi. Mereka adalah konselor pertama yang berusaha untuk menyatukan kembali dua pihak saling menjauhi, yang ditunjukkan dalam kata-kata "jika ia menolak untuk mendengarkan mereka (ayat 17a)." Mereka digambarkan sebagai orang berpartisipasi aktif dalam proses rekonsiliasi. Hal ini adalah ketika penolakan terjadi, dan hanya kemudian, bahwa mereka berubah menjadi saksi. Mereka tidak muncul sebagai saksi dalam tahap informal (kepada siapa akan mereka bersaksi); mereka akan menjadi saksi ketika masalah ini secara resmi dibawa gereja. ${ }^{36}$

Jika Matius 18:16 hanya menangani kebutuhan untuk saksi pelanggaran perdata atau pidana, maka muncul anggapan bahwa itu

\footnotetext{
${ }^{34}$ Warren W. Wiersbe, The Bible Exposition Commentary New Testment Volume 1 (Colorado Springs: David C. Cok, 2003), 66.

${ }^{35}$ Grant R. Osborne, Exegetical Commentary on the New Testament: Matthew (Grand Rapids, Michigan: Zondervan, 2010), 686.

${ }^{36}$ Adams, 60.
} 
bukan teks yang jelas memanggil kita untuk mediasi. Namun, refleksi lebih lanjut dari karakter para saksi tersebut mendorong kita untuk tidak memahami fungsi mereka secara sempit. Setelah kajian yang cermat pada ayat ini, kita dapat menemukan bahwa para saksi ini lebih menyerupai konselor daripada sebagai saksi. ${ }^{37}$

Dengan demikian jelaslah bahwa konteks ayat 16 menunjukkan saksi sebagai tindakan dengan maksud yang lebih luas dari saksi yang hanya memberikan bukti di pengadilan. Artinya, satu atau dua orang yang diambil bersama dalam ayat 16 terutama bertindak sebagai konselor, tetapi kita tidak beranggapan bahwa mereka tidak memiliki fungsi saksi. Sebab tanpa saksi, maka prosedur disiplin gereja yang diuraikan dalam Injil Matius 18:15-17 tidak dapat dilanjutkan. J. Carl Laney menuliskan,

Dalam proses hukum, tidak adanya saksi atau hanya ada satu saksi membuat sulit mempertanggungjawabkan keyakinan. Alkitab mensyaratkan saksi tambahan untuk melindungi proses peradilan terhadap tuduhan palsu, fitnah, dan tuduhan pelanggaran. Dalam proses disiplin, mereka yang telah mengamati dosa dalam kehidupan orang percaya dapat memperkuat teguran dengan mengkonfirmasi tuduhan. Para saksi juga dapat berfungsi untuk membawa objektivitas baru untuk situasi dengan membantu kebenaran muncul ke permukaan, dan bisa dipanggil untuk bersaksi jika kasus tersebut datang sebelum diumumkan kepada jemaat. ${ }^{38}$

Usaha ini dilakukan sesuai dengan tuntutan hukum Perjanjian Lama, bahwa satu orang saksi saja tidak dapat menggugat seseorang mengenai perkara kesalahan atau dosa apa pun yang mungkin dilakukannya; baru atas keterangan dua atau tiga orang saksi perkara itu tidak disangsikan. Dalam komentar ilmiahnya pada Injil Matius 18:16, Craig S. Keener mengatakan, "Meskipun murid mencari rekonsiliasi, mereka harus mengumpulkan bukti dalam urutan yang benar, kemudian perlu bukti dari apa yang terjadi (Mat. 18:16). Persyaratan dua saksi tetap menjadi pedoman prosedur peradilan pada kekristenan pada awalnya (2 Kor. 13:1-2; 1 Tim 5:19-20)."39

Hal yang paling signifikan mengenai Matius 18:16 adalah perintah Yesus untuk mengintensifkan proses dengan membawa lebih banyak orang ke dalam proses pemulihan. Hal ini tidak dimaksudkan untuk menekan si pelaku, melainkan memberi perhatian dan dukungan melalui nasihat firman Tuhan agar bertobat dari dosanya. Lewat langkah ini

${ }^{37}$ Alfred Poirier, The Peace Making Pastor: A Biblical Resolving Church Conplict (Grand Rapids, MI: Baker Books, 2006), 207.

${ }^{38}$ Laney, 53.

${ }^{39}$ Craig S. Keener, The Gospel of Matthew: A Socio-Rhetorical Commentary (Grand Rapids, Michigan: Wm. B. Eerdmans Publishing, 2009), 454. 
orang yang berdosa harus menghadapi situasi semacam proses, walaupun proses itu belum bersifat yuridis dan belum diadakan di forum yang paling resmi (pengadilan). Inti dari pemanggilan saksi-saksi adalah konfirmasi (peneguhan).

Pada poin ini diharapkan, bahwa satu atau dua orang yang dibawa untuk menghadapi saudara yang berdosa tidak harus menjadi saksi publik sebelum masalahnya disampaikan kepada jemaat. Idealnya, bahwa teguran tambahan dimaksudkan untuk mendorong perubahan hati dalam diri saudara yang berdosa di mana teguran awal tidak berhasil. Jika terjadi perubahan hati, maka saudara yang berdosa diampuni dan dipulihkan, sekaligus masalah ini berakhir. Manfaat yang diinginkan adalah pelaku menyadari kesalahannya dan bertobat, sehingga memulihkan dia dengan perilaku yang benar di hadapan Allah (1 Yoh. 1:9). Implikasinya adalah pelaku akan memahami nasihat pribadi dan bertobat. Seorang saudara sudah menang, karena telah dipulihkan kembali ke dalam persekutuan dengan Allah, kehendak-Nya, dan komunitas orang percaya; ${ }^{40}$ ia berdamai kembali ke dalam hubungan. ${ }^{41}$

\section{Teguran Publik}

Langkah ketiga dalam proses disiplin adalah melaporkan situasi kepada gereja, seperti yang terungkap dalam ayat 17a, "Dan jika ia tidak mau mendengarkan mereka (para saksi), sampaikanlah soalnya kepada jemaat." Kata kerja parakouo berbentuk aorist, aktif, subjungtif, orang ketiga tunggal yang berarti "mengabaikan, tidak memerhatikan, menolak untuk mendengarkan." ${ }^{42}$ Ungkapan ini memberikan ekspresi lebih kuat dari yang digunakan dalam ayat 16, yang memiliki ide tambahan dari ketegaran yang disengaja, dan tidak mengindahkan apa yang dikatakan. ${ }^{43}$ Sedangkan ungkapan Tell it to the Church, menunjukkan bahwa jemaat adalah pengadilan banding terakhir untuk persoalan seperti ini. Yesus menginstruksikan, "katakan kepada gereja", karena gereja ada untuk menilai materi di hadapan Tuhan dan membuat keputusan yang mengikat orang berdosa. Langkah ini sangat serius, dan jemaat sekarang memiliki tanggung jawab bersama dalam persekutuan. Gereja harus membuat penilaiannya yang didasarkan pada prinsip-

\footnotetext{
${ }^{40}$ Wayne Grudem, Systematic Theology: An Introduction to Biblical Doctrine (Grand Rapids Michigan: Zondervan Publishing House, 1994), 894.

${ }^{41}$ E. J. Bargerhuff, Lovethat Rescues: God's Father Love in the Practice of Church Discipline (Eugene, Oregon: Wipf\& Stock, 2010), 140.

${ }^{42}$ Leon Rogers Jr. and Cleon Rogers III, The New Linguistic and Exegetical Key to the Greek New Testament (Grand Rapids: Zondervan Publishing House, 1998), 41.

43John Jason Owen, A Commentary, Critical, Expository, and Practical, on the Gospels of Matthew and Mark (New York: Charles Scribner \& Company, 1870), 228.
} 
prinsip firman Tuhan dan fakta-fakta dari kasus tersebut. ${ }^{44}$ Sebagaimana Buzzard mengatakan, "Gereja memiliki yurisdiksi bukan hanya sebagai legitimasi agama, tetapi untuk semua perselisihan di antara orang-orang percaya." 45

Hal ini paling tepat dilakukan dengan membawa masalah ini menjadi perhatian para penatua, yang pada gilirannya mengawasi komunikasi untuk persekutuan jemaat secara keseluruhan. Perlu dicatat bahwa bagian ini merupakan dinamika proses pelaksanaan disiplin dalam gereja, di mana sebelum masalahnya disampaikan kepada jemaat, terlebih dahulu disampaikan kepada para penatua jemaat. Tetapi Tuhan Yesus mengajarkan, bahwa abapila saudara yang berdosa terus menolak teguran, maka perkaranya harus dibawa kepada gereja di mana dia berjemaat. Praktik ini sulit dilakukan, karena tidak mudah untuk membawa kesalahan seseorang di hadapan jemaat dan mengumumkan kesalahannya kepada jemaat. Dalam konteks masyarakat, ini semacam pemberian hukuman sosial kepada si pelaku. Walaupun demikian, langkah ini adalah langkah yang terbaik.

Menurut David L. Burggraf, bahwa alasan mengapa masalahnya disampaikan kepada jemaat adalah agar secara keseluruhan mereka mungkin memiliki kesempatan untuk membantu yang bersalah, sehingga datang pada pertobatan dan pemulihan. Setiap anggota membutuhkan pengajaran, meskipun ada langkah-langkah rumit yang harus diambil dengan hati-hati dan penting di setiap titik dalam proses di manapemimpin atau gembala bertanggung jawab, membimbing danmerawat; tetapi itu semua dilakukan dengan penuh kasih, sopan dan tertib. ${ }^{46}$ Sedangkan James Leo Garrett menegaskan,

Matius 18:15-17 mengatur bahwa ketika ada pelanggaran, baik itu moral atau relasional, di antara orang Kristen yang tidak dapat diselesaikan melalui upaya antar pribadi atau kelompok kecil, maka mereka harus dibawa kepada jemaat. Oleh karena itu, dapat disimpulkan bahwa Yesus memberikan otoritas melalui teks ini kepada jemaat sebagai pengambil keputusan dan mendukung pemerintahan jemaat tersebut. ${ }^{47}$

Hal ini mengajarkan jemaat untuk dewasa di dalam menyikapi, jika salah satu dari mereka berbuat dosa. Mereka diajarkan bahwa setiap

${ }^{44} \mathrm{R}$. Albert Mohler, "Church Discipline: The Missing Mark," The Southern Baptist Journal of Theology 4 No. 4 (Winter 2000): 22.

${ }^{45}$ Lynn Robert Buzzard, Tell it to the Church (Elgin: David C. Cook Publishing Co., 1982), 32.

${ }^{46}$ David L. Burggraf, "Principles of Discipline in Matthew 18:15-17 Part III: A Practical Study," Calvary Baptist Theological Journal 5 (Fall 1989): 19.

${ }^{47}$ James Leo Garrett, "An Affirmation of Congregational Polity," Journal for Baptist Theology and Ministry 3, No. 1 (Spring 2005): 41-42. 
orang dapat berbuat dosa dan memerlukan dukungan dari semua anggota jemaat; bukan untuk dibicarakan tanpa jelas per-masalahannya. Namun pada sisi yang lain, jemaat adalah kumpulan dari berbagai latar belakang dengan beragam karunia yang diberikan Tuhan kepadanya.

Oleh karena itu, pertimbangan dari jemaat adalah keputusan yang terbaik, asal dilakukan berdasarkan kebenaran firman Tuhan dan bukan hanya berdasarkan perasaan atau emosi semata. Pertimbangan perkara tersebut dibawa kepada jemaat bukan dengan tujuan untuk mempermalukan si pelaku, tetapi kembali untuk meneguhkan bahwa apa yang telah dilakukan oleh si pelaku adalah tidak benar dan memerlukan pertobatan. Namun, sebagai pemimpin gereja, diperlukan hikmat dan kehati-hatian agar perkara ini tidak menimbulkan konflik yang melebar dan mengancam keutuhan gereja sebagai satu tubuh Kristus. Mungkin oleh berbagai pertimbangan dalam konteks masa kini, menyebabkan dinamika dari pola Yesus sedikit diubah sebagai bagian dari kehatihatian yang serius.

Pernyataan itu menarik, di mana Yesus sendiri menyarankan bahwa orang Kristen harus membawa persoalan mereka ke gereja dan bukan ke pengadilan sekuler. Selain itu Yesus tidak mengatakan, sampaikan soalnya kepada Paus, pendeta, bishop, sinode, atau pemimpin gereja lainnya. Pada langkah ketiga ini adalah mungkin, bahwa gereja harus diwakili oleh pemimpinnya (para penatua), tetapi tampaknya bahwa Matius 18:17 dan 1 Korintus 5:4 benar-benar mencakup semua anggota gereja lokal secara spesifik. Ini berarti jemaat lokal merupakan otoritas tertinggi dalam hal disiplin. R. C. H. Lenski mengatakan, "Pada tahap ini seluruh jemaat menggunakan upaya bersatu untuk mendapatkan saudara kembali." 48

Hal ini dilakukan jika langkah kedua tidak berhasil. Harus dipahami bahwa langkah ketiga ini merupakan langkah yang dimaksudkan untuk rekonsiliasi. Sebagaimana Kristus mengatakan, sampaikan soalnya kepada gereja. Ayat 17a mengatakan, "Jika ia tidak mau mendengarkan mereka, sampaikanlah soalnya kepada jemaat." Apakah yang Kristus maksudkan ketika ia mengatakan tentang gereja? Dickson memberikan komentar demikian,

Maksud dari perkataan Kristus tentang gereja, bahwa pelaku dan saksi harus hadir sebelum para penatua gereja lokal. Ini adalah praktik di Sinagoge orang Yahudi ketika Kristus membicarakan kata-kata ini, dan itu juga dipraktikkan oleh Gereja Apostolik (Rasuli). Paulus memerintahkan Titus untuk menolak orang yang memecah-belah jemaat setelah peringatan pertama dan kedua, mengetahui bahwa orang tersebut melakukan dosa dan 1943), 701.

${ }^{48}$ R. C. H. Lenski, The Interpretation of Matthew's Gospel (Minneapolis: Augsburg, 
menyesatkan, bahkan menghukum dirinya sendiri" (Tit. 3:10-11). Kristus telah menunjuk beberapa orang tertentu dalam jemaat lokal untuk menjadi pemimpin atau pengatur atas seluruh jemaat. Orang-orang ini memiliki tanggung jawab untuk mengatasi keluhan dari orang yang terganggu, dan untuk menghapus berbagai skandal. Mereka memiliki wewenang dari panggilan Kristus untuk memeriksa, dan bahkan mendisiplin jika diperlukan. ${ }^{49}$

Selanjutnya dalam sejarah gereja, praktik teguran publik sudah dilakukan dalam Perjanjian Lama dan diteruskan oleh gereja mula-mula melalui para penatua jemaat. Samuel Miller menulis pada abad ke-19 pemerintahan gereja demikian,

Hanya ada satu bagian lagi yang akan dikemukakan dalam mendukung kelas para penatua sebelumnya. Bagian ini ditemukan dalam Matius 18:15-17. Di sini diyakini bahwa ayat 17 yang mengatakan "sampaikan soalnya kepada jemaat" memiliki referensi jelas untuk rencana disiplin yang diketahui telah ditempuh dalam Sinagoge Yahudi; dan yang artinya adalah "katakan kepada konsistori atau urusan pengadilan," yang merupakan tindakan gereja melalui perwakilan itu. Kita harus selalu menafsirkan bahasa setuju dengan pemahaman populer dan kebiasaan dalam waktu dan tempat di mana hal itu disampaikan. Sekarang, hal itu benar-benar meyakinkan bahwa frase Tell it to the Church secara terus-menerus digunakan di antara orang Yahudi untuk mengekspresikan suatu keluhan kepada para pemimpin penatua atau perwakilan dari gereja. Dan itu cukup meyakinkan, bahwa kasus-kasus aktual terjadi dalam Perjanjian Lama di mana istilah gereja (ekklesia) diterapkan pada diri para penatua (Ulangan 31:28, 30). ${ }^{50}$

Pada tahapan ini dalam proses disiplin, para pemimpin gereja memainkan peran yang sangat penting. Mereka bertanggung jawab bukan hanya terhadap saudara yang berdosa, tapi juga bagi jemaat secara keseluruhan. Mereka dipanggil untuk menggembalakan kawanan domba yaitu jemaat. John White menulis, "Tidak ada ujian yang lebih besar selain dari karunia pastoral bagi para pemimpin dalam mengarahkan banyak hal sedemikian rupa agar gereja terbangun bagi kebenaran, kesalehan dan pertobatan, sementara pada saat yang sama orang berdosa diberikan kesempatan lagi untuk bertobat."5l Komentar tersebut memberikan motivasi dan tanggung jawab seorang pemimpin atau gembala dalam jemaat. Keberhasilan pada tahap ini sangat dipengaruhi

${ }^{49}$ David Dickson, A Brief Exposition of the Evangel of Jesus Christ According to Matthew (Carlisle, PA: The Banner of Truth Trust, 1981), 248.

${ }^{50}$ Samuel Miller, An Essay on the Warrant, Nature and Duties of the Office of Ruling Elder in the Presbyterian Church (Dallas, TX: Presbyterian Heritage, 1987), 65-66.

${ }^{51} J o h n$ White dan Ken Blue, Healing the Wounded (Downer's Grove, IL: InterVarsity, 1985), 96. 
oleh sikap dan kepedulian seorang gembala kepada anggota jemaat yang melakukan dosa, dan bagaimana ia memelihara kekudusan dalam gereja.

Penolakan saudara atau saudari untuk mengakui dosanya mengharuskan hal tersebut disampaikan kepada jemaat. Penolakan anggota jemaat yang berdosa memerlukan tindakan yang lebih kuat. Seluruh komunitas Kristen dibawa ke dalam proses, bukan bermaksud menghukum pelaku, tetapi untuk membawa lebih lanjut dalam upaya rekonsiliasi. Alasan mengapa persoalan ini disampai-kan kepada jemaat, agar mereka memiliki kesempatan untuk membantu saudara yang bersalah, sehingga bertobat dan dipulihkan. Semua ini dilakukan dengan penuh kasih, sopan dan tertib. Sementara itu, Barclay menjelaskan alasan mengapa persoalan pribadi harus disampaikan kepada jemaat,

Karena persoalan tidak pernah diselesaikan dengan menempuh hukum, atau oleh argumentasi yang tidak kristiani. Legalisme hanya menghasilkan persoalan lebih lanjut. Dalam suasana doa kristianilah, kasih kristiani, persekutuan kristiani, hubungan-hubungan pribadi dapat diluruskan kembali. Asumsi yang jelas ialah bahwa persekutuan gereja bersifat Kristen, dan ingin menghakimi segala sesuatu, bukan di dalam terang buku peraturan tata tertib dan prosedur, melainkan di dalam terang kasih. ${ }^{52}$

Ayat ini juga mengajarkan, bahwa jika situasi yang melibatkan dosa pribadi terhadap orang lain tidak dapat diselesaikan melalui teguran pribadi atau teguran dengan satu atau dua saksi, maka masalah tersebut harus di bawa ke gereja. Biasanya bentuk implementasinya dilakukan melalui perkumpulan bersama dalam konteks ibadah (bandingkan Mat. 18:18-20; 1 Kor. 5:3-5). Semua dilakukan secara terbuka dan bersamasama. Apa yang mulanya harus dilakukan secara pribadi, sekarang harus diungkap secara publik karena kekerasan hati orang yang melakukan dosa tersebut. Sekali lagi tujuannya bukan untuk mempermalukan atau menghukum, tetapi untuk memulihkan.

Selanjutnya, bagian lain yang perlu dijelaskan di sini adalah kata ekklesia dalam ayat 17 yang muncul untuk kedua kalinya dalam Injil Matius (Mat. 16:18). Perlu diketahui bahwa petunjuk di sini berlaku untuk komunitas Kristen, tetapi pada saat itu mereka berbicara dari komunitas Yahudi.Sebagaimana H. Ridderbos menduga, bahwa dalam kata "jemaat setempat" pengarang Injil Matius mempergunakan suatu istilah yang telah menjadi lazim di kemudian hari..$^{53}$

Istilah ekklesia dalam Matius 16:18, Yesus sendiri memberitahukan, bahwa Ia akan mendirikan sebuah lembaga kepunyaan-Nya sendiri, 299-300.

${ }^{52}$ William Barclay, New Testament Words (Westminster: John Knox Press, 2000),

${ }^{53}$ Herr, 364-365. 
yaitu jemaat-Nya. Sejalan dengan pendapat J. Carl Laney, bahwa istilah ekklesia dalam ayat ini mengacu pada per-sekutuan orang percaya secara lokal. Ketika Yesus membicarakan kata-kata ini, organisasi gereja Kisah Para Rasul dan Surat-Surat Perjanjian Baru belum terbentuk. Tampaknya prinsip yang mendasari perintah Yesus untuk membawa masalah ini kepada jemaat, bahwa orang percaya adalah anggota dari satu tubuh (1 Kor. 12:14-20), dan memiliki tanggung jawab untuk peduli satu dengan yang lain (1 Kor. 12:25). ${ }^{54}$

Dengan demikian, maksud dari langkah publik ini adalah penguatan persuasi pastoral, bukan mempermalukan seseorang di depan publik atau pembunuhan karakter. Langkah ini sekaligus sebagai sarana edukasi bagi jemaat-jemaat yang lain. Mereka belajar bahwa walaupun gereja tidak pernah bisa sempurna, tetapi gereja juga tidak pernah berkompromi dengan dosa, terutama yang membahayakan keselamatan seseorang.

\section{Ekskomunikasi (Pengucilan)}

Yesus memaparkan langkah terakhir dalam proses disiplin terhadap orang berdosa yang keras kepala. Ia mengatakan, "Dan jika ia tidak mau juga mendengarkan jemaat, pandanglah dia sebagai seorang yang tidak mengenal Allah atau seorang pemungut cukai" (Mat. 18:17b). Mengenai bagian ini, Carson mengatakan, "Hal ini menunjukkan bahwa setiap anggota jemaat menaati hukum dalam persekutuan dan mengingatkan pembaca bahwa setiap orang percaya memiliki tanggung jawab terhadap yang lain, sebagaimana yang sudah disyaratkan dalam bentuk tunggal saudara pada ayat 15." 55 Dengan kata lain, setiap individu sebagai anggota jemaat memperlakukan saudara yang tidak bertobat sebagai kafir atau pemungut cukai. Sebagaimana J. Leeman menjelaskan,

Pendengar Matius adalah orang Yahudi yang mengerti istilah "kafir" yaitu untuk mewakili orang-orang yang berada di luar komunitas perjanjian dan "pemungut cukai" untuk mewakili orang-orang yang telah mengkhianati komunitas perjanjian (dan karena itu juga di luar masyarakat). Anggota gereja harus hidup berbeda dari dunia. Dan jika serangkaian peringatan yang lemah lembut mereka tolak, gereja harus mengecualikan mereka dari persekutuan. ${ }^{56}$

${ }^{54}$ Laney, 54.

${ }^{55}$ D. A. Carson, Matthew Expositor's Bible Commentary (Grand Rapids: Zondervan, 1984), 403.

${ }^{56}$ Jonathan Leeman, Church Discipline: How the Church Protects the Name of Jesus (Crossway: Wheaton, Illinois, 2012), 29. 
Ekspresi sebagai seorang kafir dan pemungut cukai memperkenalkan klausa perbandingan yang menggambarkan cara bagaimana orang berdosa yang tidak bertobat harus diperlakukan. Perbandingan ini dapat menjadi salah satu kesamaan (Mat. 24:27), memperlakukan dia dengan cara yang sama seperti orang yang tidak percaya diperlakukan, atau perbandingan dapat menjadi salah satu identitas (Mat. 24:37), yaitu memperlakukan dia dengan cara yang sama dengan orang yang tidak beriman. Dalam kedua kasus, individu diperlakukan sebagai orang yang tidak beriman.

Paulus dalam suratnya kepada jemaat Tesalonika mendorong mereka untuk mengucilkan saudara yang hidup tidak tertib (2 Tes. 3:14). Dia juga mendesak jemaat Korintus untuk mengucilkan orang-orang yang tidak bermoral (1 Kor. 5:9-11). Yesus dalam Kitab Injil mengajarkan tentang ekskomunikasi, sebagaimana ajaran dan instruksinya dalam Matius 18:15-17, demikian juga Paulus dalam surat-suratnya.

Objek ekskomunikasi dapat dibahas dari dua aspek, yang masingmasing sama pentingnya. Pertama, efek terhadap gereja dan kedua, efek bagi individu yang dikucilkan. Efek yang diinginkan sehubungan dengan gereja secara keseluruhan adalah memelihara kesaksian gereja, khususnya kepada orang-orang yang belum percaya. Sedangkan efek bagi individu yang dikucilkan adalah untuk membantu dia kembali pada jalan yang benar dan bertobat dari dosa-dosanya di hadapan Tuhan.

Ketika para pemimpin gereja dan jemaat telah melakukan segala upaya untuk membawa orang berdosa agar bertobat, namun tanpa hasil, mereka kemudian harus memisahkan si pelaku dari persekutuan gereja (ekskomunikasi). Ekskomunikasi berarti penghapusan resmi anggota gereja yang memberontak dari persekutuan orang percaya, seperti yang ditetapkan oleh Yesus dalam Matius 18:15-17 (lihat juga 1 Kor. 5). Dalam sisa ayat 17 , Yesus menjabarkan konsekuensi bagi orang yang menolak untuk bertobat. Yesus mengatakan untuk memandang orang tersebut sebagai orang yang tidak percaya dan sebagai pemungut cukai.

Dengan kata lain, memperlakukan orang tersebut sebagai bukan saudara Anda lagi di dalam Kristus atau bukan bagian dari gereja. Konteks ayat ini merupakan langkah terakhir dalam proses penyelesaian masalah di dalam gereja. Sebagaimana Lonzo S. Tailor mengatakan, "Ekskomunikasi adalah upaya terakhir yang dapat menyebabkan seseorang menghadapi dosanya dan bertobat. Juga melindungi gereja dari pengaruhnya yang merusak dan menghilangkan seseorang dari gereja yang dapat menjadi alasan bagi orang-orang tidak percaya untuk mengejek gereja. ${ }^{57}$ Tindakan disiplin ekskomunikasi sering dipandang oleh banyak orang sebagai hukuman. Perspektif hukuman bukanlah

\footnotetext{
${ }^{57}$ Tailor, 20.
} 
maksud Alkitab untuk ekskomunikasi, meskipun kadang-kadang orang yang berpegang pada disiplin berpikir seperti itu. Tetapi dibalik disiplin ada penebusan dan pemulihan.

Ungkapan dalam ayat 17 yang berbunyi, "tidak mau mendengarkan" memiliki arti "tidak menghiraukan" atau "mengabaikan sesuatu." Itu artinya, apabila nasihat, teguran umum, atau peringatan telah diberikan tetapi terus diabaikan, maka dalam kasus ini para pemimpin gereja dan jemaat yang telah berupaya sesuai petunjuk firman Tuhan untuk membawa orang berdosa agar bertobat, harus mengucilkan pelaku dari persekutuan gereja. Sebagaimana Laney menjelaskan,

Yesus benar-benar memerintahkan para murid-Nya agar mengucilkan mereka yang tidak mau bertobat dan memperlakukannya sebagai orang yang tidak mengenal Allah dan pemungut cukai. Dalam semboyan gerejawi ini disebut sebagai "ekskomunikasi." Kata ini berasal dari bahasa Latin ex (ke luar) dancommunico (berbagi, berkomunikasi). Hal ini mengacu pada pemutusan hubungan seseorang dari keanggotaan gereja, persekutuan, atau komunitas. Tidak mungkin lagi bahwa orang tersebut dapat berbagi dalam aktivitas dan hak-hak keanggotaan gereja. ${ }^{58}$

Anderson mendefinisikan, "Ekskomunikasi berasal dari excommunicatio yang berarti berada jauh dari komunikasi, atau yang terpisah dari persekutuan dengan komunitas orang percaya karena berbagai macam dosa atau pengajaran yang salah. ${ }^{59}$ Tetapi bagaimana pun juga, ini bukanlah berarti bahwa excommunicant sudah di luar harapan, sehingga orang Kristen mengabaikan kesempatan membujuk orang itu untuk bertobat dan dikembalikan ke gereja. R. Albert Mohler, menjelaskan bahwainstruksi untuk memperlakukan dia seperti seorang kafir atau pemungut cukai menunjukkan pemisahan itu menjadi nyata dan masyarakat. Tindakan drastis dan ekstrim ini merupkan ganjaran ketika seorang saudara atau saudari tidak tunduk pada disiplin gereja. Perlu dicatat bahwa gereja masih memberi kesaksian kepada orang ini, tetapi tidak sebagai saudara sampai ia menunjukkan pertobatan dan pemulihan yang jelas. ${ }^{6}$

Dengan demikian, istilah excommunicate secara umum merujuk kepada pengeluaran seseorang dari keanggotaan gereja, terutama persekutuan. Namun hal ini, hanya satu aspek atau bagian dari topik disiplin gereja. Sedangkan Grudem membatasi ekskomunikasi kepada

${ }^{58}$ Laney, 55-56.

${ }^{59}$ Timothy L. Anderson, Is Anathematization a Tool for the Evangelical Theologian Today? A Dissertation (Deerfield: Timothy L. Anderson, 2002), 151.

${ }^{60} \mathrm{R}$. Albert Mohler Jr., "Church Discipline: The Missing Mark," The Southern Baptist Journal of Theology 4, No. 4 (Winter 2000): 22. 
individu dalam hal disiplin gereja yang ekstrim. ${ }^{61}$ Bargerhuff menegaskan, bahwa salah satu praktik dari gereja yang benar adalah nasihat persaudaraan atau larangan, sebagaimana yang disebutkan, dalam pengajaran Matius 18 dan surat-surat lainnya, tanpa itu gereja tidak ada. ${ }^{62}$ Prosesnya didefinisikan dalam Matius 18:15-17 dan contoh aktualnya dijelaskan dalam 1 Korintus 5:1-13.

Matius memerintahkan gereja untuk memperlakukan anggota yang tidak bertobat seperti seorang kafir dan pemungut cukai (Mat. 18:15-17), dan Paulus ingin pihak yang bersalah diserahkan kepada iblis (1 Kor. 5:5), artinya diserakan ke dalam dunia setan, yakni dunia di luar gereja. ${ }^{63}$ Langkah keempat ini mungkin terdengar ekstrim di zaman kita, tetapi perlu diingat bahwa bukan suatu pilihan. Ini adalah perintah dari Yesus, sehingga kegagalan untuk melakukan hal ini di gereja adalah kefatalan.

Pengucilan adalah langkah yang sulit bagi semua orang yang terlibat. Beberapa orang berjuang untuk memahami mengapa harus melakukannya. Meskipun mungkin sulit, Yesus memanggil orang percaya untuk melakukan disiplin gereja sebagaimana dipraktikkan pada gereja mulamula. Misalnya, 1 Korintus 5, Paulus menginstruksikan kepada Jemaat Korintus untuk mengucilkan orang yang hidup dalam percabulan dan segala perbuatan kotor. Namun, perlu digarisbawahi bahwa tujuan utama disiplin gereja adalah pemulihan agar setiap orang melihat dosa mereka untuk kembali kepada Kristus dan dosa tidak menyebar lebih lanjut seperti ragi (1 Kor. 5:5-6). Ini adalah untuk kebaikan individu dan melindungi kemurnian ajaran gereja. Pada akhirnya, itu untuk kemuliaan Allah di dalam tubuh Kristus.

Art Azurdia secara sederhana menjelaskan, "Kafir diakui sebagai salah satu yang berada di luar komunitas perjanjian, dan pemungut cukai dianggap sebagai agen pemerintah kafir. Keduanya dikeluarkan dari kehidupan keagamaan masyarakat Yahudi." ${ }^{64}$ Meskipun Azurdia secara akurat menggambarkan sikap Yahudi terhadap bangsa-bangsa lain dan pemungut cukai, tetapi ia gagal untuk mengakui bahwa mereka tidak hanya dikeluarkan dari kehidupan keagamaan masyarakat Yahudi, tetapi juga dari hampir semua interaksi sosial yang positif. Secara menyeluruh, J. Carl Laney menyimpulkan,

Referensi untuk "orang kafir dan pemungut cukai" digambarkan oleh Perjanjian Baru dalam lingkup budaya Yahudi pada abad pertama. Menurut

\footnotetext{
${ }^{61}$ Grudem, 883.

${ }^{62}$ Bargerhuff, 29.

${ }^{63}$ David Noel Freedman dan Allen C. Myers, Eeerdmands Dictionary of the Bible (Grand Rapids, Michigan: Eerdmans, 2000), 438.

${ }^{64}$ Art Arzudia, "Recovering the Third Mark of the Church," Reformation e Revival 3, No. 4 (Fall 1994): 67.
} 
pendapat agama populer pada zaman Yesus, bangsa-bangsa lain dianggap sebagai orang luar berkaitan dengan berkat-berkat ilahi yang dijanjikan bagi Israel. Seorang bukan dari bangsa Yahudi tidak diizinkan untuk memasuki pelataran luar mezbah tempat kudus. Hukuman bagi yang melakukannya adalah kematian, karena melanggar kesucian mezbah. Pemungut cukai, seperti Zakheus (Luk. 19: 2-10), sebagai orang Yahudi yang mengumpulkan pajak bagi pemerintah Romawi. Mereka dianggap sebagai pengkhianat karena melayani pemerintah Romawi dengan mengorbankan negara mereka. Mereka mewakili penguasa asing yang korup. Mereka tidak patut ditiru, meskipun menguntungkan, pekerjaan itu membuat mereka sebagai orang buangan dari masyarakat Yahudi (lihat Mat. 9:10; 11:9; 21:31). ${ }^{65}$

Davies dan Allison juga berpendapat serupa, bahwa memperlakukan seseorang sebagai kafir dan pemungut cukai akan memutuskan hubungan dengan persekutuan dan itu artinya pengucilan dari masyarakat, dengan kemungkinan konsekuensi sosial dan ekonomi yang buruk. ${ }^{6}$ Lee lebih terus terang mengatakan bahwa pemungut cukai sekelas dengan pelacur, pencuri dan pembunuh. ${ }^{67}$ Demikin juga Luz menambahkan, bahwa orang-orang Yahudi yang setia pada Taurat tidak akan memiliki hubungan dengan orang seperti itu dan akan memutuskan semua kontak pribadi dengan orang tersebut. ${ }^{68}$ Ekskomunikasi bukanlah tujuan akhir disiplin gereja, melainkan sikap tegas bahwa gereja tidak pernah kompromi dengan dosa.

Ketika Yesus berbicara kepada orang-orang Yahudi (para murid), Matius menulis kepada orang-orang Yahudi (pendengar), dan saudara yang berbuat dosa telah diberikan setidaknya tiga kesempatan untuk bertobat, tampaknya masuk akal untuk menyimpulkan bahwa hubungan yang normal harus berhenti sampai saudara yang berbuat dosa bertobat, namun orang tersebut harus diinjili secara aktif. Dengan demikian, gereja mempraktikkan tujuan dari instruksi Yesus yaitu restorasi.

Penggunaan ungkapan kultural semacam ini dalam konteks disiplin gereja berarti pembatasan pergaulan. Bentuk konkret dari pembatasan ini tidak dijelaskan dalam Alkitab. R. T. France mengatakan, bahwa pengucilan dari persekutuan tidak dijelaskan secara eksplisit. ${ }^{69}$ Tetapi bagaimanapun kebanyakan penafsir menegaskan, bahwa bagian ini adalah mandat dari Kristus, paling tidak ada contoh dari ekskomunikasi yang setara dengan pengucilan dari persekutuan.

${ }^{65}$ Laney, 56.

${ }^{66}$ W. D. Davies dan D. C. Allison, International Critical CommentaryVol. 2: Matthew 8-18 (New York: T\&T Clark, 2004), 785.

${ }^{67}$ Luke C. Lee, "Church Discipline as Taught by Jesus in Matthew 18:15-20," (Thesis M.A, Western Conservative Baptist Seminary, 1991), 32-33.

${ }^{68}$ Ulrich Luz, Matthew 8-20: A Commentary (Minneapolis: Fortress Press, 20014), 52.

${ }^{69}$ France, 693. 
Kiasan "sebagai kafir atau pemungut cukai" menunjukkan lebih lanjut bahwa Matius menulis terutama kepada orang-orang Kristen Yahudi. Bangsa-bangsa lain sangat dibenci oleh orang-orang Yahudi dan benar-benar dijauhi. Hal yang sama berlaku terhadap pemungut cukai (lihat Mat. 5:46), yang karena korupsi dan bersekongkol dengan orangorang Romawi sangat dibenci dan dianggap sebagai orang terendah dalam masyarkat. Yesus di sini berbicara tentang ekskomunikasi penuh yaitu pengasingan dan pengucilan dari persekutuan (lihat Kej. 17:14; Im. 17:4; Rm. 16:17; 1 Kor. 5:9-13; 2 Tes. 3:14-15; 1 Tim. 1:19-20; Tit. 3:1-10). ${ }^{70}$ Dalam memberi makna dan penerapan disiplin gereja, Waddell berpendapat,

Konteks sastra dan konteks historis dari ayat-ayat ini tidak hanya menyoroti aspek eksklusif dari disiplin gereja, tetapi juga tujuan penebusan dan restoratif di balik disiplin. Saya menyimpulkan, bahwa memperlakukan seseorang sebagai orang kafir dan pemungut cukai berarti mereka tidak merasakan manfaat dari keanggotaan dalam komunitas perjanjian. Bagaimanapun juga, hal itu tidak berarti orang yang didisiplin berada di luar pengharapan atau bahwa orang Kristen dapat mengabaikan kesempatan untuk meyakinkan orang itu bertobat dan dipulihkan bagi gereja. ${ }^{71}$

Rencana ini adalah perbaikan, bukan menghukum. Hal ini memungkinkan orang berdosa untuk melihat gravitasi pemberontakan, sehingga ia dapat bertobat (1 Kor. 5:1-11). Ini melindungi dan memurnikan gereja serta mencegah prilaku yang buruk. Kesulitannya di sini adalah dalam hal memahami bagaimana seorang kafir atau pemungut cukai itu harus diperlakukan. John Calvin dengan jelas mengatakan, "Kita harus memutuskan hubungan dengan orang-orang yang dikucilkan dari gereja sampai mereka bertobat." 72 Demikian juga Craig S. Keener mengatakan, "Mereka harus diperlakukan sebagai seorang yang najis dan harus dihindari." 73 Sebaliknya, J. Carl Laney menyarankan, "Kita tetap mencintai dia sebagaimana Yesus mencintai pemungut cukai dan orangorang berdosa." 74

Konteks sastra dan historis dari Matius 18:17b mengungkapkan bahwa ekskomunikasi tidak pernah dimaksudkan sebagai tujuan itu

${ }^{70}$ Osborne, 686.

${ }^{71}$ Glenn G. Waddell, "The Meaning of Matthew 18:17b in its Historical and Literary Context and its Application in the Church Today," (Thesis M.A, Reformed Theological Seminary, 2014), iv.

${ }^{72}$ Calvin, 358.

${ }^{73}$ Craig S. Keener, The Gospel of Matthew: A Socio-Rhetorical Commentary (Grand Rapids, Michigan: Wm. B. Eerdmans Publishing, 2009), 454.

${ }^{74}$ J. Carl Laney, "The Biblical Practice of Church Discipline," Bibliotheca Sacra (October-December 1986): 362. 
sendiri. Artinya ekskomunikasi harus diimplementasikan dalam terang kasih Kristus, karena narasi ayat sekitarnya, justru memperlihatkan bagaimana Yesus sendiri bergaul dengan orang berdosa dan pemungut cukai, karena itu gereja harus melihat anggota yang dikucilkan sebagai ladang misi. Tetapi kebanyakan dari penafsir berpendapat bahwa ekskomunikasi adalah mandat Kristus yang tak tergantikan. Pandangan ini radikal, namun penuh ketegasan dan konsistensi yang kuat. Mungkin alasan ini, Strong dengan nada idealistik mengatakan,

Orang yang benar-benar ingin menyatakan penyesalan akan lebih mempersilahkan gereja untuk mengecualikan dia, agar dapat membebaskan diri dari tuduhan menyembunyikan kejahatan. Dia akan menerima pengecualian dengan kerendahan hati dan akan menyukai gereja yang mengecualikan dia, akan terus menghadiri ibadah, pada waktunya dia akan mencari dan menerima pemulihan. ${ }^{75}$

Bargerhuff setuju, bahwa pada kenyataannya orang yang telah dikecualikan oleh dirinya sendiri dari komunitas iman, telah berkomitmen untuk hidup dalam kebenaran. ${ }^{76}$ Oleh karena itu, model perlakuan yang tepat harus ditentukan. Apa yang menjadi ketakutan gereja mengenai praktik disiplin adalah tanpa alasan mendasar.

Namun demikian, dalam hal ini gereja perlu menggunakan akal budi kristiani untuk menentukan bentuk disiplin yang konkret. Poin yang terpenting adalah sikap gereja yang tegas terhadap dosa, tetapi penuh kasih terhadap orang berdosa. Inilah ajaran eklesiologi berdasarkan firman Tuhan yang tertuang dalam pengakuan iman gereja. Disiplin bisa diterapkan secara progresif sambil melihat perubahan hidup.

Prinsip yang paling penting untuk penerapan Matius 18:17b hari ini adalah gereja harus menemukan kembali "tanda ketiga" dari gereja yang benar, dengan mengambil sekali lagi pelayanan penting dari disiplin. Dalam melakukannya, harus dipandang sebagai kewajiban yang serius untuk mengecualikan saudara yang keras kepala dan berkewajiban untuk terus-menerus berupaya memenangkannya dengan sungguhsungguh, agar dia kembali ke gereja.

Setiap langkah dari Matius 18:15-17 hingga termasuk ekskomunikasi, harus dilakukan dengan tujuan untuk membawa saudara yang berdosa kepada pertobatan, rekonsiliasi, dan pemulihan bagi komunitas perjanjian. Ketika seorang anggota jemaat dikucilkan menolak untuk bertobat dan kembali, gereja harus menemukan kenyamanan di dalam ketaatan dan kesetiaan pada perintah Kristus. Ketika anggota yang

${ }^{75}$ A. H. Strong, Systematic Theology: A Compendium and Commonplace Book (Philadelphia: The Judson Press, 1907), 924.

${ }^{76}$ Bargerhuff, 136. 
dikucilkan bertobat, diperdamaikan dengan Allah dan gereja, serta kembali ke dalam keanggotaan, gereja harus bersukacita bahwa Tuhan telah memulihkan salah satu dari kawanan domba-Nya.

\section{Kesimpulan}

Pertama, dari segi analisis konteks. Kesejajaran kalimat-kalimat dalam struktur teks adalah petunjuk prinsip disiplin gerejawi. Ayat 15-17 mengindikasikan tatacara sederhana untuk menangani persoalan saudara seiman yang menyimpang. Prosesnya mulai dari nasihat secara pribadi, melebar ke kumpulan kecil, dan terakhir gereja secara keseluruhan. Disiplin rohani digambarkan dengan frasa "pandanglah sebagai orang yang tidak mengenal Allah (kafir) dan pengungut cukai." Secara jelas terlihat adanya unsur peningkatan pikiran alinea dalam topik itu, mulai dari tegorlah (dalam nasihat), bawalah, sampaikanlah, dan pandanglah. Ini adalah tahapan proses yang bertujun utama untuk pertobatan (restoratif), sebagaimana dimaksudkan Yesus dalam rangkaian prosedur disiplin gereja. "Aku hadir" adalah peranan Kristus sebagai kepala gereja dalam hal mengesahkan keputusan tersebut. Kristus sebagai kepala gereja hadir melalui Roh-Nya, dan kehadiran-Nya meneguhkan hukuman disiplin yang dijatuhkan. Kehadiran Yesus dinyatakan sebagai tanda keabsahan dan juga fungsi legitimasi keputusan gerejawi.

Kedua, dari segi analisis historis. Matius sebagai saksi mata kehidupan Yesus, menuliskan Injilnya tentang Kristus Juruselamat jauh setelah Yesus mati dan naik ke sorga. Di sini Matius merefleksikan permasalahan gereja mula-mula di mana ia berada. Jelas terlihat komunitas yang berasal dari kalangan Yahudi yang percaya sebagai tujuan khusus penulisan Injilnya. Pendengar utamanya adalah dua belas murid, meskipun mungkin termasuk pengikut yang lain dan mungkin juga orang banyak yang mengikuti-Nya (Luk. 8:1-3; 10:1), pada tahap pelayanan-Nya kepada orang banyak (Mat. 19:2). Tidak ada indikasi dari teks Matius 18, bahwa orang-orang Farisi atau Saduki berada di antara pendengar, hal itu berbeda dengan ayat-ayat seperti Matius 22:23-46. Matius menulis dari sudut pandang Yahudi untuk pembaca Yahudi. Istilah Yahudi dan hal-hal yang bersifat Yahudi, karena itu diharapkan para pendengar menerima dan memahami penjelasan-Nya. Misalnya, instruksi Yesus dalam Matius 18:15-17 mengenai penyelesaian masalah mencerminkan aturan dan adat istiadat yang biasa di beberapa kelompok Yudaisme abad pertama, termasuk orang-orang Farisi dan 
Essenes. ${ }^{77}$ Contoh lain, Yesus menggunakan kata "gereja" (ekklesia) di Matius 18:17 dengan cara ini menunjukkan, bahwa Dia mengharapkan kepada para pendengar untuk memahami maksud Yesus. Dengan demikian, jika dihubungkan dengan instruksi Paulus kepada jemaat Korintus (1 Kor. 5), maka para pengikut Yesus akan mengerti istilah ekklesia dalam Matius 18 merujuk pada gereja, bukan sinagoge. Alasannya, bahwa konteks historis pembicaraan Yesus merujuk kepada persekutuan yang cakupannya lebih luas (masa depan gereja). Hal itu berarti gereja sudah berkembang secara kompleks hingga sudah sampai pada permasalahan tentang pentingnya disiplin gereja. Matius mencatat perikop ini tanpa mengabaikan peran Roh Kudus dalam menuliskan kembali apa yang pernah dikatakan Yesus secara riil sebagai pergumulan khusus gereja di mana Matius berada. Di luar dari bagian utama pembahasan Matius 18:15-20, ada beberapa tema yang menonjol dari Matius 18, termasuk kerendahan hati, bahaya dosa, restorasi, rekonsiliasi dan pengampunan. Matius menulis di bawah inspirasi Roh Kudus, dikelilingi petunjuk dari ayat 15-20 dengan ayat-ayat yang mengarahkan kita kepada inti dari proses yang ditetapkan di sana. Pada sisi lain, langkah-langkah yang terdapat dalam Matius 18:15-20, hingga ekskomunikasi dari ayat 17b, harus dilakukan dalam kerendahan hati, dengan penuh kesadaran akan bahaya dosa, dan dengan tujuan mendorong pertobatan, pengampunan, rekonsiliasi, dan restorasi. Jika di lihat dari strukturnya ayat-ayat tersebut berisi instruksi yang jelas mengenai sistem aturan atau hukum dalam gereja. Namun, Parackel Mathew menyimpulkan bahwa menempatkan ayat 15-20 setelah perumpamaan tentang domba yang hilang dimaksudkan bukan hanya untuk menggambarkan sistem yuridis dari gereja lokal, tetapi juga untuk menyatakan prinsip umum bahwa setiap anggota harus melakukan segala upaya untuk membawa rekonsiliasi bagi saudara yang berbuat salah (yaitu kepada domba yang hilang atau salah satu dari anak-anak kecil dalam ayat 14). ${ }^{78}$ Konteks narasi dari ayat-ayat tersebut berbicara soal pemulihan kepada domba-domba yang terhilang atau pengampunan kepada orang-orang berdosa.

Ketiga, dari segi pertimbangan teologis. Disiplin gereja adalah salah satu materi penting dalam doktrin gereja (eklesiologi). Gereja memang diberikan kuasa untuk mendisiplinkan anggotanya, tetapi bukan untuk dipakai secara sewenang-wenang. Berdasarkan pertimbangan teologis, maka ungkapan "mengikat/kehilangan" mengacu pada ekskomunikasi

${ }^{77}$ Bridget Illian, "Church Discipline and Forgiveness in Matthew 18:15-35," Currents in Theology and Mission 37, No. 6 (December 2010): 446.

${ }^{78}$ Parackel K. Mathew, "Authority and Discipline," Communio Viatorum 18, No. 3-4 (January 1985): 123-124. 
kepada saudara yang sesat. Namun, hanya merujuk pada ekskomunikasi yang dapat menerima kembali seseorang yang bersalah berdasarkan keyakinan gereja mengenai apa yang dianggap sebagai dosa (apa yang kamu ikat di bumi) atau yang bukan dosa (apa yang kamu lepaskan di dunia). Kristus tampaknya memberikan kewenangan kepada gereja untuk menyatakan syarat-syarat Allah, baik itu mengampuni atau menyatakan dosanya tetap ada (Yoh. 20: 22-23). Oleh karena itu tampaknya masuk akal Derrett menyimpulkan, bahwa Matius 18:18 memberikan kekuatan akhirnya untuk mengucilkan yang keras kepala, tetapi teks itu sendiri berbicara tentang suatu kekuatan yang tidak terbatas dengan cara ini, artinya bukan terbatas pada soal mengampuni atau penolakan untuk mengampuni dosa. ${ }^{79}$ Kristus memberikan kekuatan kepada gereja untuk mendefinisikan apa yang merupakan pelanggaran disiplin dan untuk melaksanakan disiplin terhadap pelanggaran tersebut. Otoritas disiplin adalah anugerah, jadi tetap milik Allah, bukan milik gereja secara mutlak. Otoritas itu diberikan untuk dilaksanakan, bukan untuk disalahgunakan. Otoritas itu ada pada gereja secara keseluruhan sesuai dengan maksud Allah. Otoritas disiplin gereja dilakukan untuk kemuliaan Allah. Setiap orang Kristen harus menampilkan kemuliaan Allah yang hidup dengan cara mencerminkan kasih dan kekudusan (Ef. 3:10). Gereja yang sehat adalah gereja yang setia melaksanakan disiplin gereja yang alkitabiah. Ayat 20 dimaksudkan untuk memberikan jaminan di tengah-tengah sulitnya pelaksanaan disiplin gereja. Disiplin gereja benar-benar membawa kehadiran Kristus. Disiplin gereja adalah ajaran Kristus sendiri bagi gereja-Nya, tidak boleh diabaikan, dan juga tidak boleh dibangun di atas hegemoni kekuasaan dan kepentingan pribadi. Studi teologis yang menangani hal ini adalah hukum gereja, yaitu ketertiban, bukan semata-mata hukuman. Ini adalah tujuan disiplin gereja berdasarkan perikop ini. Penerapan lokalnya bisa saja agak berbeda, tetapi prinsip disiplin harus sama, yaitu dengan kasih Kristus, bukan otoriter dan dendam pribadi. Disiplin ini biasanya ditegakkan oleh para pemimpin jemaat, secara kolektif, sebagai pemimpin rohani. Disiplin gereja yang diajarkan Yesus bukanlah konsep teoritis, tetapi langkah-langkah praktis dalam menangani penyimpangan anggota gereja, baik dalam kelakukan maupun ajaran. Disiplin gereja pada masa kini akan meneguhkan gereja dalam menata kesuciannya sebagai umat tebusan Allah, agar tidak ragu-ragu dalam menangani kekeliruan jemaat. Namun demikian, gereja akan selalu siap menerima kembali saudara yang berdosa di dalam pertobatan dan komitmen perubahan hidupnya. Disiplin gerejawi memang sebuah otoritas

${ }^{79}$ J. D. M. Derrett, "Binding and Loosing (Matt. 16:19, Matt. 18:18, John 20:23)," Journal of Biblical Literature 102 (March 1983): 116. 
kebersamaan yang bersifat rohani, tetapi tidak boleh diperalat tanpa mementingkan kasih ilahi dan hubungan persaudaraan yang sejati. Matius 18:15-17 jelas menetapkan prosedur yang tepat sehubungan dengan disiplin gereja. Pertama, saudara berbuat dosa harus dihadapkan secara pribadi dan individual (ay. 15). Kedua, saudara yang tidak bertobat akan berhadapan secara pribadi oleh satu atau dua lagi (ay. 16). Ketiga, menyampaikan soal saudara yang belum bertobat juga kemudian soalnyadiberitahukan kepada gereja (ay. 17). Tujuan masing-masing dari ketiga langkah ini adalah untuk membujuk saudara yang berbuat dosa untuk bertobat, sehingga persekutuannya dipulihkan dalam dalam komunitas orang percaya. Keempat, hubungan normal dengan saudara yang tidak bertobat harus berhenti kecuali untuk tujuan penginjilan. Sedangkan dalam ayat 18-20 memberikan tiga janji tentang disiplin gereja:(l) Kristus menjanjikan bahwa apa pun yang gereja ikat dan lepaskan di bumi akan disetujui di sorga. Jadi mengikat/melepaskan tampaknya merupakan kewenangan untuk menentukan apa yang merupakan pelanggaran disiplin dan wewenang untuk melaksanakan disiplin untuk pelanggaran itu. (2) Kristus menjanjikan bahwa jika ada dua orang bersepakat (mungkin mengacu pada dua dalam ayat 16) tentang disiplin gereja, maka Bapa akan melakukannya bagi mereka. (3) Kristus berjanji untuk berada di tengah-tengah orang-orang yang berkumpul untuk tujuan mendisiplinkan saudara yang tidak mau bertobat.

\section{Kepustakaan}

Adams, Jay. E. Handbook of Church Discipline: A Right and Every Church Member. Grand Rapids, Michigan: Zondervan, 1986.

Alfred Poirier, Alfred. The Peace Making Pastor: A Biblical Resolving Church Conplict. Grand Rapids, MI: Baker Books, 2006.

Allen, Willoughby C. A Critical And Exegetical Commentary on the Gospel According to Saint Matthew. Edinburgh: T\&T. Clark, 1985.

Arzudia, Art. "Recovering the Third Mark of the Church." Reformation \& Revival 3 No. 4 (Fall 1994): 61-79.

Barclay, William. New Testament Words. Westminster: John Knox Press, 2000.

Bargerhuff, E. J. Lovethat Rescues: God's Father Love in the Practice of Church Discipline. Eugene, Oregon: Wipf\&e Stock, 2010.

Blomberg, C. L. Commentary of the New Testament use of the Old Testament. Grand Rapids: Baker Academic, 2007.

Brown, Harold O. J. "The Role of Discipline in the Church." Covenant Quarterly (August 1983): 51-52. 
Bubna, Donald L. "Redemptive Love: The Key to Church Discipline." Leadership Journal 2:3 (Summer 1981): 77-85.

Burggraf, David L. "Principles of Discipline in Matthew 18:15-17 Part III: A Practical Study." Calvary Baptist Theological Journal (Fall 1989): 1-29.

Buzzard, Lynn Robert. Tell it to the Church. Elgin: David C. Cook Publishing Co., 1982.

Carson, D. A. Matthew Expositor's Bible Commentary. Grand Rapids: Zondervan, 1984.

Cawdrey, Daniel. A Discourse on Church Discipline and Reformation. London: Puritan Publications, 2012.

Chouinard, Larry. Matthew: The College Press Niv Commentary. Joplin, Missouri: College Press, 1997.

David Dickson, David. A Brief Exposition of the Evangel of Jesus Christ According to Matthew. Carlisle, PA: The Banner of Truth Trust, 1981.

Davies, W. D. dan D. C. Allison, International Critical CommentaryVol. 2: Matthew 8-18. New York: T\&T Clark, 2004.

Davis, George B. "Whatever Happened to Church Discipline." Criswell Theological Review 1 (Spring 1987): 345-361.

De Heer, J. J. Tafsiran Alkita: Injil Matius Pasal 1-22. Jakarta: BPK Gunung Mulia, Cetakan ke-12, 2013.

Derrett, J. D. M. "Binding and Loosing (Matt. 16:19, Matt. 18:18, John 20:23)." Journal of Biblical Literature 102 (March 1983): 112-117.

Dever, Mark. "Biblical Church Discipline." TheSouthern Baptist Journal of Theology 4 No. 4 (Winter 2000): 28-43.

Doriani, Dan. "Forgiveness: Jesus Plan for Healing and Reconciliation in the Church (Matthew 18:15-35)." Southern Baptist Journal of Theology 13 No. 3 (2009):22-32.

Edersheim, Alfred. The Life and Times of Jesus the Messiah Vols. 2. Grand Rapids: Wm. B. Eerdmans Publishing, 1971.

Edward Hiscox, Edward. The New Directory for Baptist Churches. Philadelphia: Judson, 1954.

France, R. T. The Gospel of Matthew: The New International Commentary on the New Testament. Grand Rapids, Michigan: Eerdmans Publishing Company, 2007.

Freedman, David Noel dan Allen C. Myers. Eeerdmands Dictionary of the Bible. Grand Rapids, Michigan: Eerdmans, 2000.

Garrett, James Leo. "An Affirmation of Congregational Polity.” Journal for Baptist Theology and Ministry 3 No. 1 (Spring 2005): 38-55.

Gibbs, Jeffrey A. dan Jeffrey J. Kloha. "Following Matthew 18: Interpreting Matthew 18:15-20 in Its Context." Concordia Journal (January 2003): 6-25. 
Grudem, Wayne. Systematic Theology: An Introduction to Biblical Doctrine. Grand Rapids Michigan: Zondervan Publishing House, 1994.

Gundry, Robert. H. Matthew: A Commentary on His Literary and Theological Art. Grand Rapids: K. Eerdmans Publishing Co., 1982.

Hendriksen, William. New Testament Commentary Matthew. Grand Rapids, MI: Baker Book House, 1995.

House, H. Wayne. "Church Discipline and the Courts." The Southern Baptist Journal of Theology 4 No. 4 (Winter 2000): 60-75.

Illian, Bridget. "Church Discipline and Forgiveness in Matthew 18:15-35." Currents in Theology and Mission 37 No. 6 (December 2010): 444-450.

John Calvin, John. Commentary on a Harmony of the Evangelists, Matthew, Mark, and Luke Vol. l. Grand Rapids: Baker Book House, 1996.

Keener, Craig S. Matthew: The IVP New Testament Commentary Series. Downes Grove, IL: InterVarsity, 1997.

Keener, Craig S. The IVP Bible Background Commentary New Testament. Downers Grove, Illinois: InterVarsity Press, 1993.

. The Gospel of Matthew: A Socio-Rhetorical Commentary. Grand Rapids, Michigan: Wm. B. Eerdmans Publishing, 2009.

Kittel, Gerhard dan Gerhard Friedrich. Ed. Theological Dictionary of the New Testament. Grand Rapids: Eerdmans, 1967.

Laney, J. Carl. "The Biblical Practice of Church Discipline." Bibliotheca Sacra (October-December 1986): 353-364.

Laney, J. Carl. A Guide to Church Discipline: God's Loving Plan for Restoring Believers to Fellowship with Himself and with the body of Christ. Eugene: Bethany House Publisher, 1985.

Lange, John Peter. The Gospel According to Matthew. New York: C. Scribner, 1865.

Lee, Luke C. "Church Discipline as Taught by Jesus in Matthew 18:1520." Thesis M.A, Western Conservative Baptist Seminary, 1991.

Leeman, Jonathan. Church Discipline: How the Church Protects the Name of Jesus. Crossway: Wheaton, Illinois, 2012.

Lenski, R. C. H. The Interpretation of Matthew's Gospel. Minneapolis: Augsburg, 1943.

Lightfoot, John. Hebrew And Talmudical Exercitations upon the Gospel of St. Matthew Vol. II. Oxford: University Press, 1859.

Luz, Ulrich. Matthew 8-20: A Commentary. Minneapolis: Fortress Press, 20014.

MacArthur, John. Matthew 16-23: The MacArthur New Testament Commentary. Chicago: Moody, 1988.

Mathew, Parackel K. "Authority and Discipline." Communio Viatorum 18 No. 3-4 (January 1985): 119-125. 
Metzger, Bruce M. Textual Commentary on the Greek New Testament. London: United Bible Societies, 1971.

Mohler, R. Albert. "Church Discipline: The Missing Mark." The Southern Baptist Journal of Theology 4 No. 4 (Winter 2000): 16-27.

Morgan, G. Campbell. The Gospel According to Matthew. New York: Fleming H. Revell Company, 1929.

Morris, Leon. The Gospel According to Matthew: The Pillar New Testament Commentary. Grand Rapids, Michigan: William B. Eerdmans Publishing Company, 1992.

Mutetei, Philip. "The Proper Procedure for Discipline in the Church Part II." Africa Journal of Evangelical Theology 18 No. 2 (1999): 107-128.

Osborne, Grant R. Exegetical Commentary on the New Testament: Matthew. Grand Rapids, Michigan: Zondervan, 2010.

Rogers, Leon Jr. and Cleon Rogers III. The New Linguistic and Exegetical Key to the Greek New Testament. Grand Rapids: Zondervan Publishing House, 1998.

Russell, Walt. Playing with Fire: How the Bible Ignites Change in Your Soul. Colorado Springs: NavPress, 2000.

Samuel Miller, Samuel. An Essay on the Warrant, Nature and Duties of the Office of Ruling Elder in the Presbyterian Church. Dallas, TX: Presbyterian Heritage, 1987.

Strong, A. H. Systematic Theology: A Compendium and Commonplace Book. Philadelphia: The Judson Press, 1907.

Taylor, Lonzo S. "An Exegetical Study of Important New Testament Passages Dealing with Church Discipline." Thesis Th.M, Dallas Theological Seminary, 1974.

Timothy L. Anderson, Is Anathematization a Tool for the Evangelical Theologian Today? A Dissertation. Deerfield: Timothy L. Anderson, 2002.

Toussaint, Stanley D. Behold the King: A Study of Matthew. Portland: Multnomah Press, 1980.

Turner, David L. Matthew: Baker Exegetical Commentary on the New Testament. Grand Rapids, Michigan: Baker Academic, 2008.

Van Gorcum, Royal. Matthew and Didache: Two Documents from the Same Jewish-Christian Mileu? Minneapolis: Portress Press, 2005.

Waddell, Glenn G. "The Meaning of Matthew 18:17b in its Historical and Literary Context and its Application in the Church Today." Thesis M.A, Reformed Theological Seminary, 2014.

White, John dan Ken Blue, Healing the Wounded. Downer's Grove, IL: InterVarsity, 1985.

Wiersbe, Warren W. The Bible Exposition Commentary New Testment Volume 1. Colorado Springs: David C. Cok, 2003. 